\title{
KOMPARASI PANDANGAN FILSAFAT AGAMA \\ ALBERT EINSTEIN DAN HOLMES ROLSTON III
}

\section{Oleh}

\author{
Krisna Suksma Yogiswari
}

Mahasiswa S3 UGM

Email: yogiswarikrisna@gmail.com

\begin{abstract}
:
The effort of searching God that be done by human, some of them really find God but also many of them that be lost in the forest of Metafisisme. The discussion of philosophy and religion is the case that very interesting, even many philosophy which has been discussed about them, start from the contra until want to join both of them. In the case the contribution of philosophy and sciences is to accompany of faith to the God, within certain limits can support the various evidence of the truth of existence and the power of God which has been widely revealed by religion. Science seek the truth by research, experience (empirical) and experiment as the exam. Philosophy approache the truth with exploration of common sense in radical (rooted), it does not feel bound by any, expect by their own hands, that is logic. This study will compare the ideas of Albert Einstein and Holmes Rolston III who use the approach of science in studying the philosophy of religion.
\end{abstract}

Keyword: Philosophy of Religion, Science, Faith, God.

\section{Pendahuluan}

Manusia sebagai makhluk berakal berkemampuan merespon segala sesuatu di sekitarnya. Kemampuan akal manusia yang terus dikembangkan berpotensi menghasilkan berbagai bentuk kreasi, salah satunya ilmu. Manusia dalam menggunakan kemampuan akal tentu berorientasi pada aspek rasio guna menghasilkan ilmu yang dapat dikembangkan lebih lanjut guna kepentingan manusia. Adapun hasil ciptaan manusia berupa ilmu yang kemudian berkembang menjadi teknologi, telah menunjukkan bukti-bukti konkret kecerdasan manusia. Berbagai bentuk karya manusia tersebut berpeluang memberikan implikasi pada sejumlah hal diantaranya sikap dan pemahaman manusia dalam bereaksi atas dampak dari perkembangan ilmu.

Pembahasan tentang manusia dalam bersikap serta memahami perkembangan ilmu dapat menjadi titik tolak untuk memulai diskusi berkaitan dengan kajian filsafat agama. Hal tersebut mengingat kedudukan manusia sebagai makhluk berakal yang berkemampuan mengambil sikap dan memahami sesuatu di sekitarnya tidak dapat lepas sepenuhnya dari pengaruh latar belakang tertentu seperti bekal keilmuan ataupun orientasi agama. Orang dengan background ilmu alam misalnya, tentu berbeda dengan orang dengan background ilmu sosial ketika memandang satu peristiwa. Orang yang memiliki bekal agama tertentu dengan orang tanpa bekal agama, dapat menghasilkan pandangan berbeda pula ketika melihat satu peristiwa.

Penelitian ini akan membahas dua unsur penting yang ada dalam hidup manusia yakni akal dan keyakinan. Enstein dan Holmes Rolston III adalah dua tokoh yang lebih lanjut akan banyak dibicarakan dalam pembahasan berkaitan dengan dua unsur tersebut yang dapat menjadi awal penting menuju pemahaman lebih dalam mengenai filsafat agama sebagai refleksi kritis atas kepercayaan atau keyakinan guna menghayati pengalaman keagamaan. Pembahasan penelitian ini mengkaji esensi agama melalui kerangka pemahaman rasional yang pada akhirnya melahirkan keyakinan. Esensi agama dalam 
konteks ini dipahami sebagai suatu kepercayaan yang bersifat rasional, seperti halnya Einstein yang berpandangan bahwa aktivitas ilmiah terutama fenomena keteraturan alam semesta sebagai fenomena yang memiliki awal, memiliki pencipta. Oleh sebab itu, pembahasannya berkisar pada dikotomi pemikiran ilmiah dan religius manusia, kemudian alam semesta sebagai media ataupun objek mencapai pemahaman serta penghayatan tentang Tuhan.

Pengetahuan yang bersifat realistis, mengacu pada hukum sebab dan akibat telah ada selama berabad-abad sejak era sains dimulai. Situasi demikian tidak mengeliminasi agama. Beberapa pemeluk agama memodifikasi kepercayaan mereka untuk mengakomodasi bukti ilmiah, seperti halnya meyakini bahwa keseluruhan alam semesta yang dapat dijelaskan secara ilmiah adalah ciptaan Tuhan. Agama bertahan di tengah pesatnya perkembangan ilmu dengan cara adaptasi, terkecuali bagi agama fundamentalis, agama setidaknya menjelaskan aspek supernatural yakni hal-hal yang tidak dapat dijelaskan secara positivistik ataupun hukum ilmiah (Kurtz, 2003: 300-301).

\section{Pengertian Filsafat Agama dan Perkem- bangan Studi Ilmiah Agama}

Filsafat agama merupakan satu studi filosofis yang berusaha menemukan hal mendasar dalam berbagai perbedaan agama dengan mencari satu titik temu esensi agama hingga kemudian dapat ditemukan landasan ontologis, epistemologis, dan aksiologis. Manusia dalam ruang lingkup filsafat agama dipandang secara eksoterik yaitu sebagai satu kesatuan dengan struktur kosmis, yang memilki ikatan dengan alam ke-Tuhanan. Manusia memiliki konsep Tuhan kecil yakni bersifat personal dan Tuhan besar yang bersifat impersonal.

Objek material kajian filsafat agama ialah esensi agama yang realitanya berada di belakang suatu benda serta tidak dapat diukur dalam ruang dan waktu. Esensi agama juga dapat dipahami sebagai satu kepercayaan yang bersifat rasional. Apabila di dalam agama terdapat konsep iman yang berada pada keyakinan batin, maka memahami esensi agama dapat diupayakan dengan mencapai keyakinan impersonal terhadap fenomena alam semesta. Oleh sebab itu, esensi agama tentu merupakan dasar abstrak dalam diri manusia yang mampu memberikan motivasi agar menghayati serta mengamalkan aktivitas keagamaan.

Objek formal kajian filsafat agama adalah filsafat yang dapat digunakan sebagai kerangka pikir dalam menganalisis esensi agama. Objek formal filsafat agama berarti menganalisis segala unsur keagamaan sesuai dengan konteks ataupun arah pembahasan menggunakan kerangka berpikir kefilsafatan.Friederich Max Muller, seorang ilmuwan berkebangsaan Jerman mengusulkan disiplin ilmu baru yakni ilmu agama. Muller percaya bahwa ilmu dan agama dapat disatukan, hingga memberikan manfaat bagi keduanya dalam mencapai kerangka pikir filsafat agama. Metode-metode ilmu alam dapat dikatakan paling akurat, meskipun peneliti ataupun ilmuwan berusaha mengetahui bentuk asli perkembangan agama-agama sebagaimana yang dilakukukan oleh kaum Deis-ilmuwan mengambil prinsip umum yang membentuk hukum-hukum ilmiah perkembangan-guna menjelaskan mengapa sesuatu muncul dan apa tujuan kemunculannya (Pals, 2012: 12-18).

\section{A. Filsafat Agama Albert Einstein}

Einstein adalah seorang Yahudi Jerman yang dilahirkan di kota Ulm, Wurttenberg, Jerman pada 14 Maret 1879, dengan nama lengkap pemberian ayahnya Albert Einstein. Menurut tradisi Yahudi, seharusnya Albert Einstein bernama Abraham Einstein yaitu mengambil nama kakeknya, Abraham. Ayahnya bernama Hermann Eisntein dapat dikatakan sebagai seorang Yahudi yang tidak terlalu fanatik, karena tidak mengikuti tradisi Yahudi secara ketat. Ayah Einstein adalah seorang pedagang atau pengusaha. Ibu Einstein yang juga seorang Yahudi bernama Paulina Koch (Wardhana, 2008: 18-20).

Albert Einstein yang dikenal sebagai pemikir hebat dalam bidang fisika dan matematika. Karya Einstein berupa penemuan ilmiah banyak mendapatkan Nobel. Berbagai prestasi Einstein 
tentu membuat kagum, orang dapat mengira bahwa Einstein sudah pintar sejak kecil. Akan tetapi kenyataan tidak demikian, Einstein saat kecil mengalami gangguan pertumbuhan otak yang membuat dirinya sakit-sakitan. Einstein pun pernah divonis oleh dokter bahwa mengidap penyakit semacam autis (Wardhana, 2008: 20-21).

Masa kanak-kanak Einstein pun tidak seperti anak-anak lain pada umumnya. Einstein dikenal penyendiri dan pendiam, karena dirinya masih mengalami gangguan dalam berpikir serta berbicara. Orang tua Einstein menyikapi kondisi tersebut tidak putus asa. Orang tua Einstein selalu memberikan semangat dengan memberikan perhatian dan banyak hadiah untuk Einstein. Pada 1885, Einstein dimasukkan ke sekolah dasar Volkschule Katolik Petersschule saat berusia 6 tahun. Setelah lulus SD, Einstein melanjutkan sekolah menengah pertama ke Luitpold Gymnasium di Munich. Sejak duduk di bangku SD, ketertarikan Einstein sudah terlihat mengarah pada bidang kalkulus, matematika, dan fisika. Ketertarikan tersebut membuat Einstein kurang seimbang dalam menguasai pelajaran di sekolahnya. Einstein kurang dalam mempelajari materi ilmu sosial, akibatnya Einstein tidak lulus ujian SMP (Wardhana, 2008: 28-29).

Einstein yang tidak lulus ujian SMP tetap melanjutkan ke SMA di Swiss berbekal surat keterangan tamat belajar. Masa SMA berlalu, Einstein lambat laun menyadari bahwa pelajaran ilmu sosial tidak kalah penting dengan pelajaran ilmu eksak. Kesadaran Einstein tersebut terbukti dari penyesalannya tidak lolos seleksi masuk kuliah di Institut Politeknik Zurich karena gagal mengerjakan soal tes ilmu sosial. Einstein kemudian belajar lagi lebih serius kemudian mengulang tes seleksi kedua kalinya di Institut Politeknik Zurich hingga akhirnya diterima (Wardhana, 2008: 31).

Albert Einstein merupakan ilmuwan fisika yang berusaha memadukan dua sektor utama hidup manusia, yaitu religius (irrasional) dan science (rasional) yang meskipun demikian Einstein tidak pernah berkata dengan tegas akan motivasinya untuk memformulasikan suatu titik unik dalam menggabungkan dua aspek tersebut. Einstein bukanlah seorang Atheis, tetapi Einstein menolak segala sesuatu yang abstrak (dalam hal ini Tuhan tentunya). Sebagai bukti bahwa dia bukan seorang Atheis adalah dari perkataannya: ilmu tanpa agama sesat, dan agama tanpa ilmu buta. Einstein secara kategoris menolak segala bentuk antropomorfisme yaitu pengenaan ciri-ciri manusia pada binatang, tumbuh-tumbuhan, atau benda mati dalam pemikiran keagamaan. Einstein menegaskan bahwa Tuhan mendefinisikan diriNya sendiri, sehingga bentuk antropomorfisme memang Ia tolak karena dapat memunculkan kesan akan Tuhan personal (Jammer, 2004: 4749).

Einstein berpendapat bahwa orang yang mengetahui alam berarti mengetahui Tuhan, karena pencarian sains dalam mempelajari alam akan membawa ke agama. Pemikiran Einstein dalam terminologi teologi termasuk ke dalam teologi naturalistik yaitu pengetahuan tentang Tuhan dapat diperoleh melalui pengobservasian proses alam yang dapat dilihat dengan mata tetapi dengan ketentuan bahwa manifestasi dari yang Ilahi dalam semesta ini hanya dapat dipahami sebagian oleh intelektualitas manusia (Jammer, 2004: 55).

Agama kosmis Einstein tidak sama dengan doktrin yudaisme, kekristenan, Islam, dan agama teistik lainnya. Terlihat pada penyangkalannya terhadap konsep Tuhan personal yang memberikan paham untuk umatnya yang beriman dan berdoa kemudian memberikan mukjizat kepada mereka dengan realitas yang menentang hukum alam (mukjizat tidak dapat dipahami oleh logika alam manusia). Einstein meskipun menolak Tuhan personal, tetapi tidak memandangnya sebagai suatu penolakan terhadap Tuhan. Einstein bahkan masih menghargai tradisi dari agama tradisional. Pernyataannya mengenai "Ilahi menampakkan diri-Nya melalui benda-benda fisik", dapat menjadi satu bukti pendukung penolakannya kepada orang-orang yang menganggap dirinya ateis.

Hingga saat ini, masih banyak orang dari ilmuwan maupun filosof, mereka-reka akan 
keyakinan agama yang dianut oleh Einstein hingga pada akhirnya dapat dikatakan bahwa Einstein adalah penganut Pantheisme (kemauan untuk menerima semua agama tanpa harus menjadi seseorang yang fanatik terhadap satu agama saja). Pengaruh pemikiran Einstein akan filsafat disebabkan banyaknya buku-buku filsafat yang telah ia baca seperti Boruch Spinoza, David Hume, ataupun Immanuel Kant. Pemikiran Einstein tentang agama dan hubungannya dengan ilmu pengetahuan membuahkan beberapa artikelartikel penting yang di dalamnya berisi penjelasan bahwasannya Einstein menolak eksistensi dari suatu pertentangan yang tak dapat ditanggulangi antara Ilmu Pengetahuan dan Agama, dan mengklaim bahwasannya konflik yang terjadi antara keduanya lebih disebabkan oleh masalah non substansial. Einstein dalam karya artikelnya berjudul "The World As I See It", dengan tegas menolak doktrin akan Tuhan personal, karena dia menganggap bahwa Tuhan lebih bersifat Maha Hadir dan tak terbatas oleh ruang dan waktu, sehingga merupakan suatu hal yang naïf jikalau Tuhan digambarkan dengan wujud akan pikiran manusia (Jammer, 2004: 122).

Menurut Einstein, tidak ada hal yang kontras antara Agama dan Ilmu Pengetahuan jika masingmasing benar-benar diperlukan. Ilmu pengetahuan adalah pembelajaran tentang penjelasan suatu hal, sedangkan agama lebih menitik-beratkan pada etika antara manusia dengan manusia dan manusia dengan Tuhan. Sudut pandang agama lebih independen dibandingkan ilmu pengetahuan, karena agama mencakup nilai-nilai keseimbangan yang terdapat pada ranah keilmuan seseorang. Kepastian arah suatu agama adalah untuk menumbuhkan prinsip-prinsip etika untuk mencari akhir dari nilai kehidupan ini. Tidak ada suatu pertimbangan yang masuk akal.

Einstein dalam analisis untuk mencari kesinambungan antara agama dengan ilmu pengetahuan mengidentifikasikan tiga konsep keTuhanan yang berbeda sesuai dengan tiga fase berbeda akan evolusi pemikiran religi. Pertama, sebelum manusia sadar akan hukum-hukum yang mengatur hubungan sebab-akibat antara fenomena alam, maka ada kecenderungan langsung menganthropomorphic-kan (me-makhluk-kan) hal tersebut. Konsep yang pertama ini disebut konsep "Ketakutan”. Kedua, konsep “Ke-Tuhanan, Sosial, ataupun Moral". Pusat perhatian dari sosial dan moral yang bersumber pada praktek keagamaan menggambarkan Tuhan sebagai seorang ayah yang melindungi, memberikan hadiah, memberikan kenyamanan, bahkan memberikan hukuman bagi anak-anakNya yang melanggar nilai-nilai sosial dan moral. Ketiga, "Cosmic Religious Felling" yakni perasaan religius akan alam semesta. Jika konsep pertama dan kedua menggambarkan Tuhan sebagaimana pikiran manusia, maka dikonsep ketiga ini Einstein menolak akan ke-Tuhanan yang anthropomorphic dalam hal indrawi. Tuhan tidak dipengaruhi oleh hukum alam, Tuhan lebih luas dan lebih besar dari pada itu. Einstein percaya akan Tuhan yang impersonal yang tidak berkaitan dengan takdir manusia, tetapi Tuhan mengungkapkan diriNya sendiri dengan tujuan memberikan keharmonisan di dalam alam semesta ini (Jammer, 2004: 89-95).

\section{B. Ilmu dan Logika Agama Holmes Rolston III}

Holmes Rolston III adalah Profesor Filsafat di Universitas Negeri Colorado. Rolston berpendapat bahwa ilmu dan agama sama-sama memiliki penjelasan tentang dunia, meskipun berdasar pada paradigma yang berbeda. Ilmu memahami dunia dengan cara menemukan penyebab-penyebab terciptanya segala sesuatu, sedangkan agama menemukan makna-makna dalam memandang fenomena di dunia. Ilmu dan agama berbagi pendirian bahwa dunia dapat dipahami melalui logika (Rolston, 1996: 467).

Makna dan sebab memiliki konsep pemahaman yang umum, tetapi arah ataupun jenis orientasinya berbeda-beda. "Sebab" telah membuktikan kesulitan dalam menjelaskan dugaan secara lengkap. Beberapailmuwantelah mencoba untukmenjelaskan penyebab menggunakan variabel, tetapi kebanyakanilmuwanmerasa sulituntuk melepaskan diri darikeyakinanbahwa variabelyang bermanfaat saling terhubung. 
Variabel yang memuat penjelasan satu pokok tertentu pun pada satu titik melibatkan unsurmakna di dalamnya (Rolston, 1996: 467-468).

Ilmu sebagai bidang yang mencari penyebab dari segala sesuatu secara tidak langsung terbatas oleh ukuran pengamatan empiris. Hubungannya konstan, disertaioleh gagasan yang sulit dipahami dari yang diperlukan oleh hasil konsekuen dalam memprediksi peristiwa duniawi. Penyebab diketahui, prediksi dimungkinkan, dan efek umumnya dapat dijelaskan jika penyebabnya diketahui, terutama jikaada hukum yang memberikanlogika tertentu sebagai proses keilmuan. Hukum, meskipun memungkinkan prediksi deduktif, hanya menyediakan awal peengatahuan, yang selanjutnya masih memerlukan beberapa kejelasan seperti masa keteraturan dalam hubungan antara sebab dan akibat.

Ilmu menyatakan bahwa kausalitas berjalan jauh di dalam suatu hal, agama menyatakan bahwa terdapat nilai tertinggi dalam sesuatu. Hal tersebut menunjukkan bahwa sulit menemukan makna tanpa agama. Ilmuwan sosial dan psikolog yang tidak setuju mengenai apakah ilmu mereka melibatkan makna di dalamnya, dan teka-teki sejauh mana subyek manusia dapat dipahami kausal telah meninggalkan ilmu pengetahuan manusia tentang kekhawatiran. Meskipun ilmuwan sosial atau psikolog mungkin mempertanyakan arti memiliki orang lain dan bagaimana fungsi orang lain di dalam hidup mereka. Ilmuwan sosial dan psikolog berpendirian kuat bahwa ilmu berguna untuk menemukan makna bagi diri mereka sendiri (Rolston, 1996: 468).

Ilmu ini dapat menggambarkan makna bahwa orang lain tidak menghayati makna pada mata pelajaran dan hanya menjadikan hal lain sebagai objek studi. Hal demikian berbeda dengan seseorang yang dengan ilmunya menemukan makna dalam struktur dunia ataupun struktur budaya, kemudian memasukkan dalam orientasi kehidupan. Dengan demikian, dalam ilmu pengetahuan manusia dapat ditemukan tumpang tindih antara sains dan agama bahwa ilmu pengetahuan adalah studi tentang penyebab dan agama adalah penyelidikan makna terdalam segala sesuatu.

Setiap paradigma besar hampir tidak bisa ditawar, terdapat dogma dalam disiplin ilmu. Paradigma tersebut muncul dari pengalaman. Ilmuwantelahmenemukanbanyakhubungansebabakibat, sedangkan agamawan telahmenemukan banyak makna. Ilmuwan menyadari seperti kebermaknaan yang diuniversalisasi ke dalam keyakinan bahwa segala sesuatu adalah kausal berurutan dan bahwa semua peristiwa yang bermakna ditafsirkan. Dalam ilmu pengetahuan modern ini menghasilkan hukum alam semesta yang tepat, yang dapat menguntungkan orang berhasil mempelajari dan memanipulasi. agama menghasilkan kebermaknaan kumulatif alam semesta yang fokuspada Tuhan, Mutlak, ataukeIlahianseluruhalam (Rolston, 1996: 469).

Disposisi ini untuk menafsirkan hal-hal bermakna yang dibangun ke dalamstruktur-struktur dalam pikiran. Kausalitas pada ilmu pengetahuan serta signifikansi pada agama berhenti pada tataran psikologis yang terlibat dalam struktur logis pikiran. Pikiran telah berkembang secara alami dalam merespon lingkungan di mana terjadi kehidupan. Pikiran individu turut memberikan pengaruh bawaan dalam meringkas pengalaman (Rolston, 1996: 469).

Perdebatan antara ilmu dan teologi sering dengan upaya memperjelas hakikat sejauh kausal yang kompatibel dengan atau bertentangan dengan makna penjelasan. Perselisihan tertentu dapat memunculkan klaim untuk masingmasing wilayah, agama dan ilmu. Ilmu dengan menggambarkan alam, menempatkan kendala pada konsep Tuhan yang Maha Besar dan Segalanya, meskipun ilmu pengetahuan dengan deskripsi ilmiah memberikan penjelasan tentang keberadaan Tuhan (Rolston, 1996: 471).

Temuan makna tidak sesederhana seperti mengidentifikasi hubungan kausalitasnya. Maknahadir disetiap kesempatan sering dapat diintegrasikan ke dalam kebermaknaan sementara dibawah hukum sebab akibat yang tidak relevan. Adamakna religius berulang seperti ketika orang menemukan kembali pentingnya pengampunan, 
cinta, pengorbanan. Ada berbagai mode menarik pikiran manusia, tidak semua pikiran manusia berorientasi ilmiah ataupun agama. Sains dan agama berbagi model penyampaian teoritis. Keduanya ingin beroperasi dari model atau teori, plot atau pola, yang memberikan kejelasan universal apa yang diamati dalam fenomena tertentu. Ukuran khusus dalam komposisimakna pada agama tentu dapat membuat kejutan, tetapikejutannyatacukupmengacaukanteoriyang berlaku. Hal tersebut disebabkan oleh model ilmiah dituntut dapat menjelaskan fenomena keseluruhan, sehingga ketika ilmu tidak mampu menjelaskan ataupun memprediksi fenomena kemudian melibatkan unsur agama di dalamnya (Rolston, 1996: 473).

\section{Filsafat Agama Albert Einstein dalam Konsep Ilmu dan Logika Agama}

Albert Einstein sebagai seorang ilmuwan yang dikenal gemar mendengarkan musik klasik, memiliki pandangan tersendiri tentang filsafat agama serta konsep ke-Tuhanan. Pemikiran Einstein akan Tuhan yang impersonal dipengaruhi oleh teori fisikanya tentang relativitas, yang dalam penelitiannya Einstein menemukan bahwa ruang dan waktu tidak bersifat statis tetapi selalu berubah dan bergerak. Einstein pun mulai mengambil kesimpulan, setiap benda yang bergerak pasti ada yang menggerakkannya, karena tidak mungkin pergerakkan benda mendahului benda itu sendiri. Dari kesimpulan yang sederhana ini, akhirnya Einstein mulai membuka pikirannya tentang halhal yang abstrak (Tuhan), karena hanya dialah yang mampu menembus serta mengisi ruang dan waktu pada saat bersamaan.

Konsep Cosmic Religious Feeling Einstein merupakan titik tolak pembahasan filsafat agama, sebab perasaan religius dalam memandang alam semesta dapat menempati ruang penghayatan seseorang dalam memaknai esensi agama. Hal tersebut menunjukkan bahwa bagi Einstein setiap orang dapat memegang keyakinan agama tertentu dengan beragam manifestasi ibadah yang berbedabeda. Akan tetapi, seseorang yang memegang teguh keyakinan satu agama pada level tertinggi dapat mencapai penghayatan penuh atas makna agama dengan melibatkan unsur perasaan dalam memandang alam semesta.

Adapun kerangka pikir ilmu dan logika agama yang dikemukakan oleh Holmes Rolston III dalam memandang filsafat agama Einstein menunjukkan beberapa kesamaan, khususnya pada orientasi konsep awal dan akhir alam semesta. Pembahasan terkait konsep awal dan akhir alam semesta tidak terlepas dari klaim-klaim ilmiah ataupun teori penciptaan alam semesta. Einstein yang mengemukakan tiga tahap pandangan keagamaan manusia menjelaskan fase pemahaman seseorang dalam memaknai agama. Pertama memakhlukan alam semesta sebagai bagian dari hal supranatural, kedua mulai memegang konsep agama langit, ketiga mencapai tahap pemaknaan agama melalui perasaan religius memandang alam semesta.

Fase tersebut sebagaimana diungkapkan oleh Rolston bahwa manusia dalam dirinya memiliki kecenderungan berpikir secara rasional dan nonrasional. Kecenderungan berpikir yang rasional mengarah pada konteks keilmuan, sementara berpikir nonrasional mengarah pada konteks hal-hal abstrak seperti agama ataupun Tuhan. Dua kecenderungan tersebut meskipun mengarah pada konteks yang berbeda, tetap memiliki penjelasan logis dalam memandang alam semesta. Kecenderungan berpikir rasional dalam konteks keilmuan menjelaskan secara logis tentang alam semesta, seperti menemukan penyebab-penyebab yang terjadi pada alam semesta. Kecenderungan berpikir nonrasional seperti dalam konteks logika agama, memahami fenomena alam semesta sebagai sebuah proses pencapaian makna esensial agama.

Perspektif ilmu dan logika agama dalam memandang filsafat agama Einstein menjelaskan bahwa fenomena alam semesta yang dapat dicerap oleh indra manusia, mampu memunculkan berbagai produk pemikiran manusia diantaranya teori ilmiah yang menjelaskan alam semesta serta pemahaman akan makna agama. Pada tataran keilmuan ataupun pada fase awal konsep filsafat agama Einstein menunjukkan rasa keingintahuan 
manusia menemukan rahasia di balik keteraturan alam semesta. Pada ruang lingkup ilmiah, ilmuwan berupaya melakukan beragam eksperimen guna menemukan penyebab-penyebab yang dapat menjelaskan alam semesta. Einstein pada tahap pertama filsafat agama pun mengungkapkan hal serupa yakni menunjukkan fase awal pemikiran manusia merespon segala sesuatu di sekitarnya dengan memakhlukan alam semesta.

Pada kerangka pikir logika agama, seseorang dikatakan berhasil mencapai esensi agama apabila dirinya telah menemukan makna terdalam merespon segala hal yang dicerapnya sebagai sebuah fenomena keagamaan. Einstein pada tahap akhir filsafat agama juga menekankan konsep Cosmic Religious Feeling sebagai pencapaian tertinggi manusia dalam memaknai Tuhan dan agama. Hal demikian menunjukkan bahwa manusia dalam menjalani proses kehidupan melalui beberapa masa pemahaman akan halhal yang mengatasi dirinya. Seiring dengan perkembangan zaman serta banyaknya fenomena alam semesta yang unpredictable, pengetahuan manusia semakin bertambah. Seseorang dengan tingkat keingintahuan tinggi dapat tertantang untuk mencari tahu segala penyebab di balik rahasia kebesaran alam semesta, hingga kemudian menemukan makna yang menghubungkan penghayatan keagaman ataupun ke-Tuhanan.

Adapun perspektif ilmu dan logika agama memandang filsafat agama Einstein mengarah pada kecenderungan manusia memahami fenomena alam semesta, khususnya berkaitan dengan awal penciptaan alam semesta beserta pemaknaan kehidupan. Kecenderungan manusia memahami fenomena alam semesta berkaitan dengan awal penciptaan ditunjukkan oleh adanya upaya ilmuwan bereksperimen guna mengetahui penyebab pertama yang mendesain keteratutan alam semesta. Hal tersebut sebagaimana Einstein yang menyatakan bahwa "Penyebab" tidak mungkin ikut serta ke dalam sebab-sebab yang ditimbulkan-Nya, dalam konteks ini berarti Tuhan dikatakan hanya bertugas menciptakan kemudian manusia mencari penjelasan-penjelasan logis akan ciptaan-Nya.
Kecenderungan manusia memahami fenomena alam berkaitan dengan pemaknaan kehidupan ditunjukkan oleh manusia yang berupaya menggunakan akal untuk berpikir guna mencari penjelasan logis tentang agama sebagai jalan memahami Sang Pencipta alam semesta. Baik Einstein maupun Rolston, memiliki kemiripan dalam memandang tahap akhir manusia menuju esensi agama yakni menyatukan logika serta perasaan untuk mendapatkan pengetahuan, pemahaman, serta pemaknaan agama secara filosofis. Dengan demikian, seseorang yang berhasil mencapai level tersebut dapat dikatakan mampu memegang teguh iman, keyakinan, dan ajaran agama yang berimplikasi langsung pada kehidupan sehari-hari. Manusia pada posisi tersebut dapat menyatukan kemampuan berpikir secara ilmiah sekaligus logika agama demi meraih penghayatan akan esensi agama.

\section{Komparasi Pemikiran Albert Einstein dan Holmes Rolston III dalam Kerangka Filsa- fat Agama}

Einstein dan Holmes Rolston merupakan dua pemikir yang memiliki pandangan tentang filsafat agama. Dua pemikir yang bertolak dari logika dalam memandang filsafat agama ini memiliki kesamaan dan perbedaan. Kesamaan pemikiran Einstein dan Rolston terletak pada prinsip bahwa pemahaman filsafat agama dapat diperoleh melalui pemahaman fenomena alam semesta. Keduanya saling menganalisis fenomena alam semesta dalam kerangka keilmuan, hanya saja Einstein lebih mengembangkan dasar logika matematis ke arah hukum-hukum fisika, sementara Rolston lebih mengembangkan teori logika kausalitas.

Letak kesamaan pemikiran Einstein dan Rolston juga dapat terlihat pada kesetujuan akan konsep Sang Pencipta yang menggerakkan serta mengatur keseluruhan alam semesta. Einstein dan Rolston memiliki kesamaan pendapat bahwa berbagai bukti ilmiah yang digunakan untuk menyusun argumen tentang alam semesta tidak sepenuhnya dapat memberikan penjelasan mendasar. Hal tersebut terbukti dari adanya potensi kejadian unpredictable di tengah aktivitas 
riset ataupun eksperimen terhadap alam semesta, bahwa segala bentuk pengembangan argumen tentang alam semesta baik dalam bentuk teori ilmiah maupun klaim logika kausalitas belum sepenuhnya mampu memberikan penjelasan filosofis tentang alam semesta.

Einstein dan Rolston mengungkapkan rasa ingin tahu lebih dalam tentang alam semesta dengan memunculkan argumen yang dapat dikatakan masuk kategori nonrasional. Einstein menyebut argumen tersebut dengan istilah tahap penghayatan alam semesta, sedangkan Rolston menyebutnya dengan pemaknaan alam semesta. Dua bentuk argumen tersebut menunjukkan bahwa ilmuwan dengan karya-karya fenomenal pada satu waktu berpeluang merasakan ada sesuatu yang kurang dalam argumen rasionalnya. Ilmuwan pada satu titik tertentu mempertanyakan rahasia ataupun alasan metafisis yang ada di balik keseluruhan alam semesta.

Adapun perbedaan dari pemikiran Einstein dan Rolston terlihat pada pemahaman akan konsep ilmu dan agama. Einstein berpendapat bahwa ilmu dan pengetahuan mengandung berbagai penjelasan yang mendukung penghayatan keagamaan, sedangkan Rolston menyatakan bahwa berbagai argumen logis dalam ranah keilmuan terpisah dari pemaknaan keagamaan. Hal tersebut berarti, Einstein memandang hubungan antara ilmu dengan agama sebagai dua unsur yang saling melengkapi untuk mencapai esensi agama melalui penghayatan alam semesta. Berbeda dengan Rolston yang beranggapan bahwa ilmu dan agama memiliki ruang masing-masing yang terpisah dan berbeda satu sama lain, ilmu menjelaskan hubungan sebab dan akibat di dalam benda-benda alam semesta, sedangkan agama mengungkap satu nilai yang mengatasi benda-benda alam semesta.

SatuungkapanAlbertEinsteinyangbermakna filosofis yaitu "Ilmu Tanpa Agama Buta, dan Agama Tanpa Ilmu Lumpuh”. Ungkapan Einstein tersebut menunjukkan satu pengertian bahwa ilmu yang dapat terus berkembang hingga membawa kemajuan bagi umat manusia membutuhkan satu landasan metafisis demi menjaga keterarahan perkembangan ilmu. Agama yang memuat nilai- nilai kebaikan dari Tuhan memberikan arahan dalam orientasi pengembangan ilmu. Hal tersebut diperlukan agar ilmuwan senantiasa menyadari bahwa prestasi besar yang telah diraih tidak dapat lepas dari keterlibatan Tuhan. Ada fase dimana pada satu eksperimen ataupun aktivitas ilmiah, ilmuwan mengalami kegagalan dan kegamangan. Fase tersebut menunjukkan bahwa keberhasilan dan kegagalan sebuah rencana tidak dapat ditentukan oleh ilmuwan. Manusia tidak dapat memastikan kemajuan ilmu, sehingga peran agama dalam hal ini menjaga kesadaran ilmuwan sebagai manusia biasa yang memiliki keterbatasan.

Ungkapan agama tanpa ilmu lumpuh dapat berarti bahwa keseluruhan unsur dalam agama yang mengandung konsep Ketuhanan dan memberikan pengetahuan kepada manusia tentang nilai-nilai transendental, mengarahkan pemikiran manusia pada hal-hal di luar dunia. Manusia dengan keyakinan keagamaannya dapat seketika menerima dogma agama tentang kehidupan dunia dan akhirat tanpa berani mempertanyakan kebenarannya. Akan tetapi, apabila pengetahuan keagamaan tidak diiringi dengan ilmu maka kehidupan manusia di dunia dapat kurang seimbang. Manusia menjadi kurang mengoptimalkan kemampuan akalnya dalam mengolah segala hal yang telah ada di dunia. Tanpa ilmu, berbagai fenomena alam semesta akan sulit diterima oleh akal manusia karena tidak adanya media yang memberikan ruang olah pikir rasio manusia sebagai satu upaya menemukan penjelasan logis tentang alam semesta.

\section{Kesimpulan}

Pandangan Albert Einstein tentang filsafat agama menekankan pada pencapaian konsep ke-Tuhanan impersonal, bahwa manusia dapat mencapai jalan menuju Tuhan dengan cara memahami serta menghayati fenomena alam semesta melibatkan perasaan religius. Einstein menguraikan tiga tahap pemahaman filsafat agama seseorang sesuai peradabanumatmanusia. Pertama, tahap tradisional yaitu manusia memakhlukan segala sesuatu di sekitarnya. kedua, tahap doktrin agama yaitu manusia mulai mengenal agama 
sebagai satu keyakinan yang menjadi pandangan hidup serta mengikat kehidupan manusia. Ketiga, tahap perasaan religius kosmis yang bagi Einstein merupakan titik akhir manusia mencapai esensi agama.

Penjelasan ilmu dan logika agama memiliki agrumen yang berbeda dengan Einstein dalam menjelaskan pemahaman esensi agama. Holmes Rolston III sebagai seorang filsuf juga profesor yang berkarya di bidang filsafat mengungkapkan bahwa ilmu dan logika agama memiliki paradigma berbeda dalam menjelaskan alam semesta. Ilmu berorientasi pada teori ilmiah tentang fenomena alam semesta yakni menemukan penyebabpenyebab yang mengatur pergerakan alam semesta. Logika agama mengarah pada proses pencapaian makna terdalam dari keseluruhan fenomena alam semesta yang berimplikasi langsung pada kehidupan keagamaan sehari-hari. Keduanya mengklaim memiliki penjelasan rasional dalam menjelaskan dinamika alam semesta.

Einstein hingga akhir hayatnya tetap mencari keselarasan dan berusaha memadukan antara agama dan ilmu, tetapi belum dapat diungkap oleh Einstein hingga akhir hayatnya. Hal tersebut disebabkan bahwa ruang lingkup agama dan ilmu memiliki kedudukan masing-masing. Ilmu dan agama dalam perspektif Rolston pun dapat berjalan beriringan ketika pemahaman keilmuan meningkat ke arah pemaknaan kehidupan dengan menghayati fenomena alam semesta. Pembahasan keseluruhan makalah dapat memunculkan tiga penjelasan landasan filsafat agama secara ontologis, epistemologis, dan aksiologis. Ontologis mengacu pada esensi agama, epistemologis pada metode manusia mencapai pemahaman ataupun pengetahuan keagamaan melalui logika dalam memandang alam semesta, dan aksiologis pada nilai ke-Tuhanan impersonal.

\section{DAFTAR PUSTAKA}

Jammer, Max. 2004. Agama Einstein: Teologi dan Fisika. Yogyakarta: Yayasan

Relief Indonesia

Kurtz, Paul (ed). 2003. Science and Religion.
New York: Prometheus Books Pals, L. Daniel. 2012. Seven Theories of Religion. Yogyakarta: IRCiSoD

Peterson, Michael.1996. Philosophy of Religion: Selected Readings. New York: O x f o r d University Press

Wardhana, Wisnu Arya. 2008. Einstein Mencari Tuhan. Yogyakarta: Pustaka Pelajar 